\title{
The Supporters of Unification and the
}

\section{Taiwanisation Movement}

Feelings of emergency and a crisis mentality hover in the Blue camp during the 2004 presidential election campaign

\section{Stéphane Corcuff}

\section{(2) OpenEdition}

\section{Journals}

Electronic version

URL: http://journals.openedition.org/chinaperspectives/2942

DOI: 10.4000/chinaperspectives.2942

ISSN: 1996-4617

\section{Publisher}

Centre d'étude français sur la Chine contemporaine

\section{Printed version}

Date of publication: 1 May 2004

ISSN: 2070-3449

\section{Electronic reference}

Stéphane Corcuff, "The Supporters of Unification and the Taiwanisation Movement », China

Perspectives [Online], 53 | May- June 2004, Online since 29 December 2008, connection on 28 October

2019. URL : http://journals.openedition.org/chinaperspectives/2942 ; DOI : 10.4000/

chinaperspectives. 2942

This text was automatically generated on 28 October 2019

(c) All rights reserved 


\section{The Supporters of Unification and the Taiwanisation Movement}

Feelings of emergency and a crisis mentality hover in the Blue camp during the 2004 presidential election campaign

\section{Stéphane Corcuff}

\section{EDITOR'S NOTE}

Translated from the French original by Philip Liddell

1 The spring 2004 presidential election in Taiwan seems to have set a particular milestone in the process launched in 1986 of liberalisation, democratisation and democratic consolidation ${ }^{1}$. The rival camps exchanged wild attacks during the campaign; and a proportion of the losers, mostly supporters of unification with China, staged demonstrations afterwards, their refusal to admit defeat bolstered by the victors' narrow majority. This reaction, by its nature and intensity, expressed the camps' disquiet over the long-term prospect of political eclipse, in the context of ever deepening Taiwanisation. Other demonstrators, not necessarily pro-unification even though they had voted for what is known as the pan-Blue (fanlan) coalition ${ }^{2}$, were making a dramatic comment on Taiwan's economic situation over the past four years. Their view, which was extremely negative, was partly influenced by the opposition's electoral propaganda, given that the economic indicators had been showing positive growth for seven months before the election.

2 Taiwanese democracy has certainly survived the post-electoral demonstrations, described by former President Lee Teng-hui as "an attempted coup d'état". But, with the passing of the crisis, the question posed by the losers' attitude remains unanswered: how stable are the democratic values of those unification supporters most unhappy about Taiwanisation? For fifteen years they have been aware of the downward trend of their political influence; and some of them now see in democracy itself a threat to their cherished but time-worn ideal: unification between China and Taiwan. 
3 This crisis is probably the first very significant obstacle to the democratisation process launched 18 years ago. What does it tell us about the importance of identity in Taiwan's political development? What does it say about the stability of democracy in the island, or about the loyalties of those who have the most to lose in the present transition but who, with their political influence, could still thwart or hold back the policy followed by the pro-independence campaigners now in power?

4 Despite the undeniable qualities of democracy, it is a form of government that, like the others, does not create unanimity. In Taiwan, as elsewhere, democratic rule is regularly attacked by those for whom democracy means loss of power. A youthful democracy, as Taiwan's is, can still be threatened from within, even when it appears firmly established. Historians of fascism and the twentieth century dictatorships have shown that democracies are not always guaranteed to survive. From this lesson has arisen the concept of "democratic consolidation".

5 This article analyses one of the underlying causes of the attacks made on democracy by the Blues, implicitly and explicitly, both during and after the 2004 presidential election campaign: the psychological factor, within the context of politics and identity. Only a few references will be made to the campaign by the pro-independence camp, known as the pan-Greens (fanlï) ${ }^{3}$. Indeed, the article concerns itself above all with the psychology of the defeated. To this end, it asks two simple questions: how is it that the opponents of the President could have wielded, with unfailing determination, arguments whose polemical aspects were easy to spot, arguments that were passed on without critical comment by many media and that so many people found convincing? The second question follows on from the first: how firmly attached to democracy can these people be, when they feel that present developments challenge their power and their ultimate political aim, namely, the ideal of unification?

\section{WHAT INDEPENDENCE?}

According to one's angle of approach, Taiwan's effective independence appears quite differently: now absolute, now incomplete, now legal or now political. It is perfectly clear that Taiwan is independent in reality: no other government than that of the Republic of China has raised taxes or designated a leader in Taiwan since 1949. Most importantly, the independence of Taiwan exists in law; that is a legal fact, though one that is strongly disputed: the government that holds power in the island holds in its own hands the totality of attributes that international law and doctrine prescribe as the sine qua non of formal sovereignty. People often contest this argument by citing Taiwan's lack of international recognition: they suggest that Taiwan's sovereignty exists, perhaps, de facto, but not de jure.

Yet, this view may meet with objections. The first, theoretical: sovereignty is as much a legal notion as political, and political as much as legal. Historically, this is how the sovereign nation-state was defined in the Peace of Westphalia in 1648. It is specious to distinguish the two notions, and basically rather illogical: is a sovereign nation that is not recognised as such no longer sovereign? Such reasoning leads to insoluble legal and political situations, as it has in Taiwan, which according to this theory is in a legal vacuum that has nothing to do with its practical situation.

A second objection is practical: even if international recognition were a necessary legal criterion of sovereignty, Taiwan would fulfil this condition. It would be enough for one tiny micro-state, a member of one single international organisation requiring its members themselves to be considered sovereign states, to recognise the island officially: this alone would satisfy the legal argument. And there do exist about thirty sovereign states, members of the United Nations, that recognise Taiwan.

The third objection is legal: international law does not include the criterion of 
recognition among the elements of sovereignty-this is often forgotten. Neither recognition by one state nor recognition by all the states nor admission to the United Nations constitutes an indispensable legal condition of sovereignty in the external order"; and, indeed, the condition would be unmanageable. How many states would it take, recognising another, to confer sovereignty upon it? Was Switzerland deemed a sovereign state in fact but not in law over the decades during which it was not a UN member? Unfortunately, the argument put up against Taiwan is at best an imperfect analysis or a pseudo-legal justification of a political argument that is necessarily debatable.

The problem, in judging whether "independence" and "unification" are valid alternatives, is even more complex if we ask which government we are talking about. While Taiwan is definitely independent, it is so, in law, only as the Republic of China, not as Taiwan. For the time being, the notion of Taiwan is political (and historical, geographical, cultural, artistic...) but not yet clearly constitutionalised; and those states that maintain official diplomatic relations with the island recognise it as such.

The Republic of Taiwan perhaps exists politically, even institutionally, but its existence at the strictly constitutional level is limited, for the present, to the "additional articles to the Constitution of the Republic of China", which substantially modify the functioning of the 1947 Constitution without altering its historical dispositions. Indeed, the constitutional reforms were not voted through as amendments (xianfa xiuzheng an) but as articles additional to the Constitution (xianfa zengxiu tiaowen); they were added in several waves since 1991; and this solution avoided, for a while, having to change the Constitution, which would be a politically risky reform. In no case has the state's name been changed, and it is still the Republic of China. In a word, Taiwan as such is certainly not independent in law, being so only as the Republic of China. So, in this intricate situation, what does it mean to say "the independence of Taiwan"? Independent of whom? Independent of what? Independent of the People's Republic of China? Certainly not, since Peking has never governed the island since the PRC was founded on October 1st 1949. That is why the Taiwanese pro-independence movement has never claimed independence from the People's Republic. From the Republic of China itself? That is precisely what the pro-independence campaigners ask, because they perceive the island's official government as being inherited historically from that which governed on the mainland between October 1911 and December 1949, being in their eyes unconnected with Taiwan's history or with its present-day political reality. Thus, the question is more about changing the name of the country (gai guohao) and not about severing political connections with China, which have not existed for fifty years.

6 Among the losers, there are some people today who think that democracy is merely a tool in the hands of the ideologues building the Taiwanese nation. The validity of this clear-cut view is, of course, worth examining; however, the idea that representative democracy might be "captive" was not born in Taiwan and is not in the least bit new to the debate on democracy: it even has a historical foundation, and a certain political justification ${ }^{4}$. Its seductive power, over those who have lost an election or who feel themselves lastingly excluded from the democratic process, is all the greater. Thus, the argument has cropped up again and again on Taiwan's path to democracy. The leaders of the Blue camp gave this idea fresh currency during their speeches to the demonstrators, after rejecting the results of the presidential poll on March 20th. 


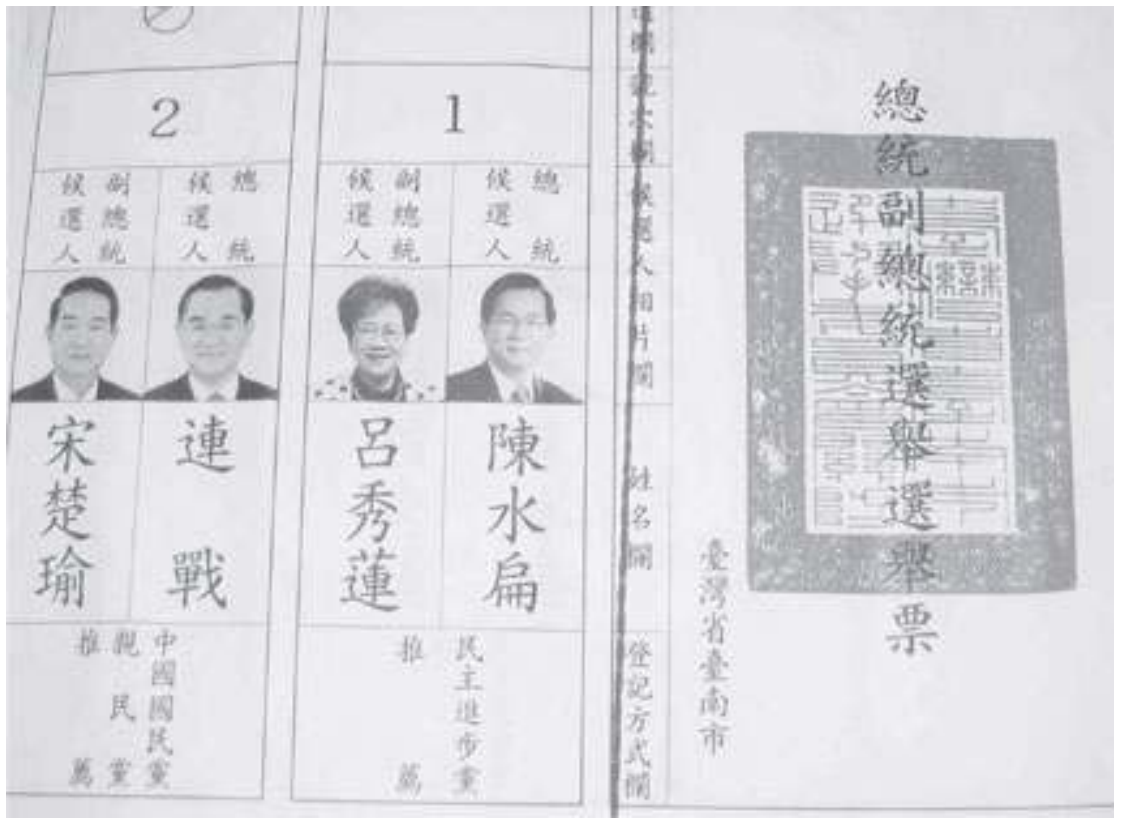

(c) Stéphane Corcuff

7 Supporters of the policy of Presidents Lee Teng-hui and Chen Shui-bian find it quite legitimate to harness democratic power to the aims of identity reform, on the grounds that the past dictatorship imposed on Taiwan a Chinese identity, nationalist, uniform and basically invented, an identity alien to the island and to its multi-cultural heritage; that the Nationalists achieved this by coercive and sometimes violent methods; and, lastly, that this policy has irremediably impaired the local cultures. There is, for many of them, a sort of legitimate "revenge", which the more moderate see as a necessary restoration of a "balance" after the excesses of the past, in what is now called by some "post-colonial" (houzhimin) phase of the republican Chinese government on Taiwan"

On the other hand, those who feel Taiwanisation (bentuhua) to be a threat to the island's Chinese cultural heritage do not accept what they judge as the use of state power to redefine the people's identity. Inevitably, their critique of Taiwanisation tends to slide into an attack on democracy itself; after all, it is democracy that, in three successive elections by direct universal suffrage, in 1996, 2000 and 2004, has raised two pro-independence Taiwanese men to the presidency ${ }^{6}$. The democratic process, which gave expression to a long-suppressed Taiwanese identity, went on to challenge the categorically imperative status given (until Lee Teng-hui's presidency began) to the aim of unification with China. The question arises: what of those for whom unification remains the ultimate political goal, what feelings do they have towards the democratic idea? For some people today, there is a real opposition between the preference for democracy and the preference for identity.

Since the early 1990s, the unifiers most opposed to Presidents Lee Teng-hui and Chen Shui-bian have been condemning with equal persistence what they perceive as the dictatorship of the two democratic Presidents. But behind the rhetorical references to democracy (minzhu tizhi) or to dictatorship (ducai tizhi), the thrust of their reproach is really aimed at the objectives of this power, rather than at its extent. In Argentina, the generals started denouncing the "creeping dictatorship" of the democratically elected 
President the day that he called them to account for the tortures inflicted under the dictatorship they had imposed. Similarly, the most vehement critics of Presidents Lee Teng-hui and Chen Shui-bian denounce presidential power all the more because they no longer wield it themselves: the political logic is quite straightforward. They perceive presidential power, even though it is in fact quite limited ${ }^{7}$, turned against them. In former times, most of them supported the dictatorship, then quite real, of Chiang Kaishek's "free China". But, in fact, there is no contradiction here. The explanation for this apparent inconsistency is that they are sticking to their aim of unification: a principle maintained by the old regime but called into question by the new. And, for the same reason, they support one and attack the other. There is nothing new, either, in their opposition to Taiwanisation ${ }^{8}$. So it is hardly surprising that they should attribute their growing political marginalisation, in a changing environment, to "personal dictatorship".

10 The attacks on a Taiwanese pro-independence campaigner now in power, made by unifiers of mainland origins feeling their influence declining irreversibly, are something more than the stale rhetoric of those losing out because of democratisation. The attacks show the permanence of the unifiers' loyalty to a basic value, unification with China, whereas democracy remains a value that is non-essential (even though not necessarily ornamental).

11 The more radical of the unifiers have today a sense of urgency, linked to a question of an existential nature: confronted by a strong historical force tending to marginalise them and fence them in with contradictions sharpened by the democratic process, what are their chances of political survival? The question is the more pressing since the aim of unification between Taiwan and China is beginning to lose its sacred aura, not merely in Taiwanese society but also within the mainlander population of Taiwan itself, penetrated by an irrepressible movement towards identification with the island.

12 While the feelings of crisis and urgency among the leaders of the Blue camp do not necessarily show through in the carefully worded replies to formal interview questions at party headquarters in Taipei, they are evident at the local or central level to anyone who can sound out the unifiers' psychology, or to anyone who frequents mainlanders with no political role, in their everyday private life. We would be wrong to imagine that, because the unifiers have also been "Taiwanised" and because opinions vary within their camp, this feeling of crisis is restricted to the extremists alone or to the older generation. The sense of crisis is widely shared. The shock of Taiwanisation, which might have been in some ways, and in spite of the psychological crisis they were already experiencing at that time, dying away during the last years of Kuomintang under Lee Teng-hui ${ }^{9}$, is today a renewed source of unease and anxiety, as this Taiwanisation deepens, as it normalises the pro-independence leaders' presence in power and as it allows the first pro-independence leader elected as head of state to be returned for a second term.

13 To show how deep are these feelings of crisis and urgency, this article seizes upon a particular political moment, a revealing moment, during which these complex feelings reach a climax: the moment when the unifiers' camp learned the news, on the evening of Saturday March 20th, of its third electoral defeat since the presidential election of 1996, a moment that seemed to confirm its collapse for the duration. In our view, the politicians of the Blue camp, who had difficulty in finding a common, coherent and convincing strategic response to the challenge set for them by the Taiwanisation 
movement, no longer had the initiative of the political calendar. To attempt to reverse their very delicate position in this decisive phase of Taiwan's history, faced with a Green camp now firmly in power (and a Green economic record that had improved just before the start of the campaign and had robbed them of their main argument) they now launched a campaign of unexpected but predictable violence, playing on the Chinese threat, appealing to the conspiracy theory and depicting Chen Shui-bian as a dangerous dictator.

We are concerned firstly with the notion of identity, different interpretations of which lead to radically different approaches to the question of Taiwan's future. Then we shall deal with the origins of the crisis by attempting to characterise a "mainland effect", sociological as much as political, even geopolitical, to demonstrate the importance of the mainlanders in Taiwan. This will help us in looking for the basic faultline in Taiwanese society on the question of identity: less "independence versus unification" than "Chinese consciousness versus Taiwanese consciousness". We shall see what a complex form is taken by the national identification of the mainlanders in Taiwan, a necessary preliminary to understanding the supporters of unification faced with ultimate defeat, the re-election of Chen Shui-bian: he was fairly elected, admittedly, but in an unacknowledged three-cornered contest, and backed now by a higher vote than in 2000 .

During this year's campaign, we have witnessed a real crisis of identity. The war of words has been fierce beyond control, one camp desperate not to see Taiwan back in the hands of a party suspected of appeasement towards China, and the other glimpsing with unequalled anguish the possibility of annihilation. A fight to the death: a sadly illuminating example can be cited, if one were needed, in the joy displayed by many militants in the Blue camp when the assassination attempt on Chen Shui-bian was announced. How did we reach that point?

If we attempt to reflect at the level of democratic theory, notably from the viewpoint of transitology (i.e., the study of transitions to democracy and democratic consolidation), the central question posed by this crisis is: what are the prospects for Taiwanese democracy to flourish over the fifteen years ahead? It faces three formidable challenges.

17 Firstly, there is the debate over identity within Taiwanese society, which is becoming increasingly bitter. The elections force politicians on both sides to make choices and to mark their preferences; they make people drop their masks; and they reveal, a little more each time, the vertiginous depth of opposition between two visions of Taiwan's identity. Then, there is the pressure from the Chinese who, lacking the strength in conventional weapons to invade the island, have found a more effective strategic solution in deploying an ever-growing number of missiles; while the reality of this threat is still under debate, the pressure it applies is like lighting a fire under an already boiling pot. And lastly, there is the veto from the international community, which is unwilling to guarantee Taiwan's security. While the US is committed to defending the status quo, it will not support any change to it. As for the rest of the world, it will not guarantee Taiwanese security in any circumstance, and frequently reads into Taipei's sovereignty discourse a vain exercise in nation-state building, nineteenth century style, even a "Taiwanese nationalism" that it judges to be implicitly dangerous because it "provokes" China. This judgement is understandable, but illinformed ${ }^{10}$. The point is, the international community's strategy towards Taiwan has a 
direct political impact on the Taiwanese debate: it plays in favour of the supporters of unification, even though they are today in the minority. These three pressures considerably reduce the margin for manoeuvre for the island's leaders. The latter cannot change the country's name (they would not have any national consensus, while this decision would lead to a rejection by the international community); nor can they submit to China (being the elected leaders of a sovereign country, even one not recognised as such, they could not win support for this political act in the democratic context of Taiwan); and neither can they curb the debate over identity (because of the risk of being accused of stifling democracy itself). Thus, the men and women involved in Taiwan politics, in both camps, are in a delicate situation.

What do we mean by "identity"?

18 These three pressures are inextricably linked to a central notion, identity. We frequently have of it, by default, an intuitive perception, one that turns out to be partially wrong: that of an identity-state (I am ...), of an identity-having (I have ...), or of an identity-heritage (my roots are ...). Yet, identity is neither a state, nor a havingbeyond the strict genetic baggage with which we come into this world. Where identification can be analysed, identity is indescribable because it is an infinite process, an ever ongoing process. Though this may be obvious to psychologists, anthropologists and quite a number of sociologists, ordinary people have an instinctively fearful reaction to identity change, despite the fact that this is the common fate of all mankind. We find it difficult to consider our identities as naturally constructed, evolving and pluralistic-I am necessarily a little more myself today than I was yesterday; and this causes the transition of the national identity in Taiwan, like any transition of identity, to be instinctively perceived as dangerous: something worryingly unknown, a shake-up of the established order, a political manipulation, an unacceptable loss of that state which, even so, is not identity, or of that "having" which it will never be.

19 The identity transition frightens those who, on the island of Taiwan, remain marked by fifty years of political socialisation, of "Greater China" nationalism and who, identifying themselves nevertheless with Taiwan at the everyday level, are not exempt from contradictions. But these contradictions are quickly exploited by the supporters of unification, and they have a political cost. On the one hand, the supporters of unification refuse to consider the elected President as the supreme and legitimate authority; they say the assassination attack was made "on Chen Shui-bian", not "on the President of the Republic". On the other hand, in a second consequence that is just as fundamental, they consciously attempt to destabilise this President, though he has been democratically elected and re-elected, to vent their frustrations and to enable themselves to believe that the historical movement of which they are casualties is not inevitable.

The identity transition also frightens those, on the mainland, who have convinced themselves since 1949 that Taiwan is an inalienable part of China, to the extent of its becoming an essential element in the Chinese national psyche post 1949, whereas any dispassionate analysis of history (to mention only this one approach) might bring one to challenge many such certainties. Did not the Chinese Communist Party itself advocate the independence of Taiwan during the 1930s? Did not Mao Zedong himself, before coming to power, recommend that China be divided into several more easily manageable states? 
Counting the votes, 20 March: ballot is picked up by the first election officier, opened by a second, read ans show to the public by a third, and finally recorded on a list in full view of public by a fourth

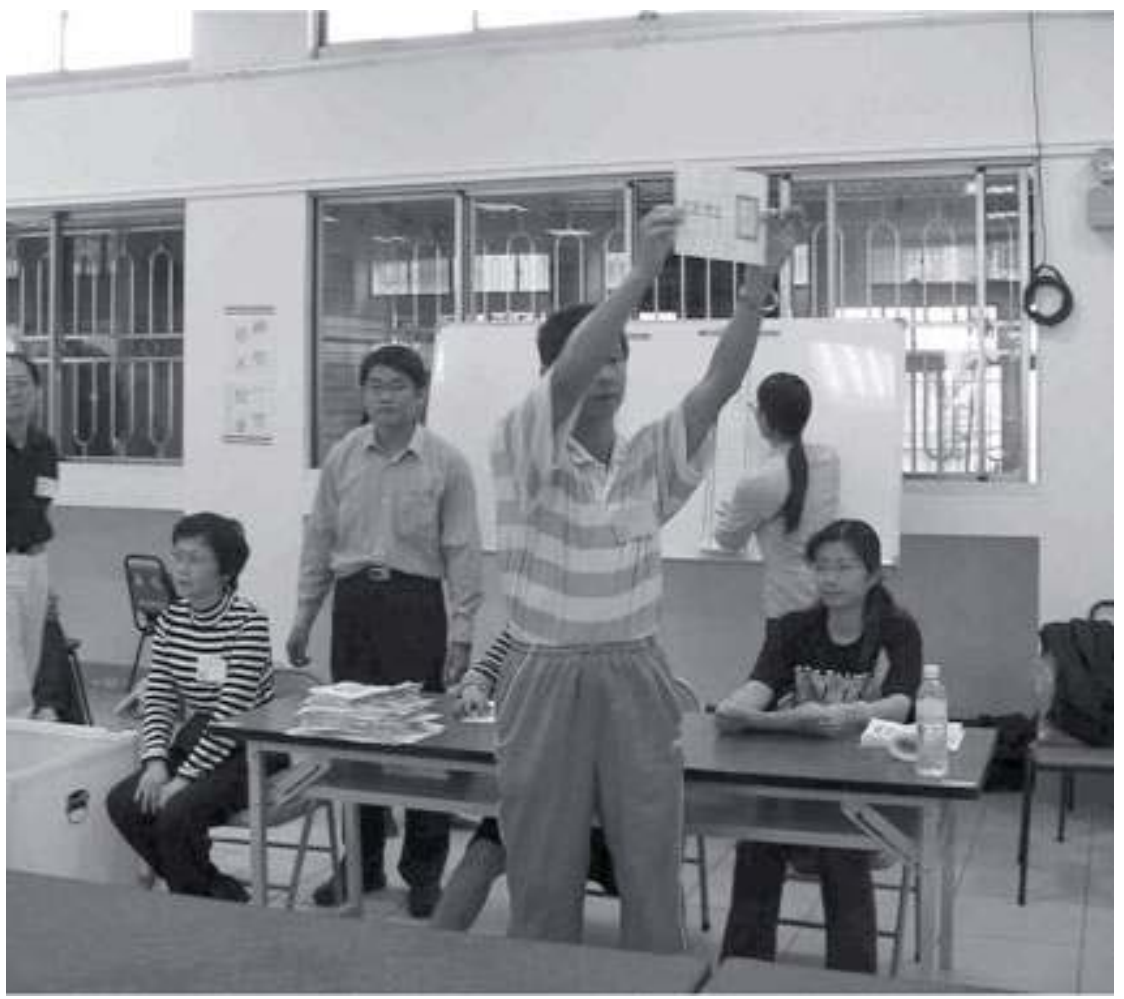

(c) Stéphane Corcuff

21 Lastly, the identity transition frightens those in the international community who are seduced by the status quo. This is still apparently the most convenient solution, in the very short term, even though it would be challenged (the Taiwanese are excluded from the UN; the Taipei government is well and truly sovereign; the consensus over Taiwan's Chinese identity, on which the status quo is historically based, has disappeared).

Students of the Taiwanese question may easily agree in recognising that there exists a debate about identity in Taiwan. However, it is not always easy to distinguish its various faultlines, or to identify one that would help us to distinguish the two camps on a single essential point, more clearly and less arguably than the others.

The "Waishengren phenomenon" in Taiwan

Let us begin with the opposition between mainlanders and Taiwanese. The Waishengren are those Chinese immigrants who arrived in Taiwan from various mainland provinces between 1945 and $1955^{11}$, their numbers rising to a peak at the time when the Nationalist government relocated to Taipei in December 1949. Those whom we currently call "the Taiwanese" are also of mainland origins, but older ones; their ethnic makeup is equally diverse: Minnan or Hakka. As we have shown in an earlier contribution to this review ${ }^{12}$, the building of an ethnic, political, symbolic and psychological frontier between the two can be historicised: we can thus determine the main dates. Obviously we are not concerned here with an ancestral or immutable frontier, but with one that was constructed. Many misunderstandings between the two communities, and resentments on the part of the Taiwanese faced with mainlanders monopolising power, developed over a forty-year period. Inter-communal marriages 
and the phenomenon of the military exodus from the villages ${ }^{13}$ have allowed a level of adaptation to Taiwan of the values of everyday life, ways of living and language among the mainlanders, whereas the first generation has gradually died out and the young people born of mainland parents have no personal experience of China. Our own work on the mainlanders, which was aimed at a statistical measurement of the phenomenon of national identification, shows the unstoppable progress of adaptation to Taiwan that permeates the daily life of the mainlanders; but nothing would justify the assertion that the "provincial origin complex" (shengji qingjie) might have disappeared at all moments of daily life, or even less in situations where politics are uppermost in people's minds. And it reappears regularly, every time electoral polls force mainland or Taiwanese electors to make choices. And let us not forget the power and influence that second generation mainlanders kept for themselves, taking over from their elders in political and media circles. Admittedly, these younger people identify far more than their parents with Taiwan, but they certainly have not abandoned the principle of unification. That principle takes a pounding, at the moment when the Taiwanese come to power in their own land.

The mainlanders, a minority estimated at approximately $12 \%$ of the population, have held onto power in a proportion far outweighing their numerical strength in the media, the army, the administration and parliament. Their national identification is partly in conflict with the movement towards the indigenisation of the political structures and the ideology of Taiwan. There exists, then, a "Waishengren phenomenon" in Taiwanese society and polity. But is this to say that the present conflict can be explained by a basic opposition between mainlanders and those of Taiwanese origin? If that were true, electoral behaviour would reflect it: we would note a massive vote by mainlanders for mainlanders and for programmes stamped with the unifiers' ideology; and a massive vote by Taiwanese for Taiwanese and for pro-independence programmes. No trace of such a clear dichotomy can be found. While $80 \%$ of mainlanders are reputed to vote for mainland candidates, whose policies mostly reflect the rejection of accelerated Taiwanisation, of abandoning the Chinese heritage with its aim of unification, the opposite is not true among those of Taiwanese stock. While the latter did vote en masse for candidates of Taiwanese stock, the mainlanders would have not had for a long time the slightest political hope in the island. Consequently, while there undoubtedly does exist a Waishengren phenomenon in Taiwan, the faultline does not lie along the Waishengren-Taiwanese divide.

Independence or unification?

So, what about the independence/unification faultline and its bearing on the island's future? It is probably significant, just like the mainlanders/Taiwanese divide but, here again, nothing indicates that it is the most important faultline. In reality, notions of independence or unification are ambiguous. In theory, there should not be any opposition between, on the one hand, the choice of independence and, on the other, that of unification. Indeed, there would be a problem of logic: if the question of unification is being asked, then there must already be independence; if the question of independence is being asked, how can it be offered at the same time as the option of unification? The true opposition lies elsewhere, between the advocates of unification (or of reunification) and those calling for a change in the country's name (gai guohao): from "Republic of China" to "Republic of Taiwan" ... among other possible choices. 
26 To characterise "unification" implies a choice between its various forms, and this is where the divisions begin: under which government should the two sides of the Taiwan Strait be unified? How soon? Under what conditions? Under the flag of the Republic of China? That is hardly realistic, given the disparity of force between the two sides-although the candidate Lien Chan wrote, during the campaign, that this would be his option. Under the colours of the People's Republic of China? That solution would be difficult to sell to the Taiwanese, who live in a democracy and choose their own sovereign leaders. Under a federation, to which both governments would sacrifice their present names? It might be a viable solution, but only on condition that the two governments accept it. The options being numerous, and Taiwan being hardly in a position to dictate terms, the advocates of unification are themselves divided.

27 As for the pro-independence camp, the proposal to change the country's name has, seemingly, the merit of clarity. But once the real debate begins over what name to adopt, the options are, here again, numerous. Will the choice reflect a desire for a complete psychological break or, conversely, will it assert independence while seeking a name acceptable to China? Will it be "Taiwan" (Taiwan guo), the "Republic of Taiwan" (Taiwan gongheguo) or, for example, a "Chinese Republic of Taiwan" (Zhonghua Taiwan minguo), the last solution being the least unacceptable for China? Furthermore, in the pro-independence camp, not everyone supports changing the country's name. Many say that they would favour first changing the Constitution, so as to avoid providing China with too easy a casus belli while allowing the main changes in practical terms; that is the view of President Chen Shui-bian. The pro-independence camp is no more unified over the formal aspects of independence than is the unification camp over those of unification ${ }^{14}$. The independence/unification debate is, indeed, an important faultline but, like the earlier examples, does not lead us to a satisfactory clarification of the real divide between the two sides.

"Chinese consciousness" and "Taiwanese consciousness"

Does there really exist a central faultline on which everything depends? Let us examine a final opposition, which we propose here, and which is based on the notion of consciousness. This notion, linked to ethnic identification (Waishengren/Taiwanese) as well as to the choice offered for the island's future (independence/unification), does not, however, come down to either the one or the other, and encompasses both of them. Those putting this notion into words set "Chinese consciousness" (Zhongguo yishi) against "Taiwanese consciousness (Taiwan yishi)"15. This "consciousness", which takes on the clothing of an ideology ${ }^{16}$, is at the same time ethnic, cultural and political (in the civic sense). You might say of someone in Taiwan that, for example, his Chinese consciousness "is very strong": but he would not necessarily be a mainlander. He could even possibly be against unification (or against unification at any price)-but would probably not be in favour of independence. Similarly, some very Taiwanised mainlanders will unambiguously reject the Chinese political system, but not the option of future unification, and there is no contradiction here. They do identify with Taiwan but do not subscribe to an independence that their Chinese consciousness, unlike their Taiwanese consciousness, bars them from thinking as legitimate or useful. Which probably means that, for a doubtless considerable number of Taiwanese (mainlanders and those of Taiwanese stock), the independence/unification faultline says nothing very precise about what they really think. 
Having a strong "Chinese consciousness" or "Taiwanese consciousness" does not necessarily prejudge a person's position on independence or on ethnic origins. Thus, the "consciousness" variable, whether it be Chinese or Taiwanese, is more subtle and less simplistic; it also explains more. One may identify oneself with Taiwan in everyday matters but keep, by virtue of one's parental upbringing and past political socialisation, a strong Chinese consciousness. Thus, Taiwanese people who speak Taiwanese, being mainlanders widely Taiwanised in everyday matters and using the Taiwanese language, will maintain their opposition in principle to independence, and will feel a systematic mistrust for Chen Shui-bian: this would be difficult to explain other than by the significance of this variable. Alongside rational analyses of a political assessment of such and such a variable (cross-Strait relations, for example), where subjectivity is strong but thinking remains rational, there exists among the Waishengren an opposition in principle to independence and an adherence in principle (markedly diminished, however) to the ideal of unification, views that are not properly "rational" and that spring from the individual's inherited ethnic identification and from received political socialisation. And often, speeches that are supposed to explain unification, ranging from those of the less educated of unification supporters, to those with more carefully thought out arguments put forward by others, often reveal contradictions. One may encounter the logical fallacy common to many speeches by re-unifiers throughout the world: "Why is independence not desirable? Because Taiwan is part of China." This fallacy is known as petitio principii, or begging the question: a method of reasoning that takes as its argument, and holds as already established, the very conclusion that it seeks to prove. Its use is commonplace among advocates of unification, on both sides of the Strait.

Whether you examine the unifiers' position or that of the independence camp, you very soon view apparent contradictions or political manipulations, in a country where emotion has in large part driven reason out of the political debate. This leads to an unprofitable analysis of the situation. The pro-independence people, for example, often accuse their opponents of manipulating public opinion. This is largely true of many politicians in the Blue camp, and the presidential election campaign this year has demonstrated it to a remarkable degree. But the mainland politicians are also, just like the Taiwanese mainlanders, grappling with their own pluralistic identity. They are confronted with conflicting notions: their identification with Taiwan, which is undeniable, the persistence of their political socialisation, and the image of an ideal China. Are some of the Blues manipulative? Of that there is no doubt; but most of the mainlanders simply have their heads filled with an emotional ideology-Greater China -which obliterates their reasoning capacity. This is most evident in the case of the mainlanders born in Taiwan, who have never been to China, and who consider Taiwan as their "country" (some indeed call it guojia), but are in principle opposed to independence. They justify this position with the argument that it would be likely to lead to war; but they also say, “... because Taiwan is part of China". Nothing, other than the persistence of the teachings of past political socialisation, can explain what, at first sight, looks like a contradiction.

31 It is this complex result, an always personal mixture of cultural and ethnic identification and political socialisation, that we call here "Chinese consciousness" and "Taiwanese consciousness". These consciousnesses are not exclusive of each other; one can find them together in an infinite variety of proportions, which go to make up the 
richness of the Taiwanese expression of identity ${ }^{17}$. The result of this March's election does not show, in our view, an opposition between mainlanders and Taiwanese, or a 50-50 split over the questions of independence and unification (on this point the opinion polls give totally different results), or even an opposition between a "mainlander ideology" (waishengren yishi) and any other. The result shows that Taiwanese society is split between two visions of Taiwan: one is the fruit of the new Taiwanese consciousness, and the other is created by the persistence of the Chinese consciousness. We should take care to avoid the cut-and-dried conclusion that "the Taiwanese" do not want independence, or that Taiwanese nationalism is "on the rise". But it is true that there are trends. A basic trend-and one that is growing fast over recent years in Taiwan-is that people describe their ethnic identification as Taiwanese, rather than Chinese. And while these presidential elections have been fought over the division between "Chinese consciousness" and "Taiwanese consciousness", judging by the particularly marked increase in the personal vote won by Chen Shui-bian between 2000 and 2004, we might have here a second obvious trend.

The complexity and fluidity of identification in Taiwan

It is difficult to understand the phenomenon of opposition between "Chinese consciousness" and "Taiwanese consciousness" without first going more deeply into the question of identification with the national model. The experience of identity by the mainlanders in Taiwan is marked, on the one hand, by a conflict between their identification with Taiwan at an everyday level and, on the other, their reflex vote for candidates favouring unification. The Taiwanese often consider that "the Waishengren" do want unification, and that supporters of unification, often identified, though misguidedly, with the Waishengren, are ready to sell Taiwan out to China in order to achieve their ideal of unification with the Chinese mainland. These judgements, shared by the most committed politicians, as by the average Taiwanese, and the least politicised, have only a partial foundation in truth.

In a study lying between political science and social anthropology, aimed at discovering how the Waishengren really feel for Taiwan as a potential object of identification, we attempted to determine the variables that might help to measure statistically the phenomenon of identification with the national model. A questionnaire with 178 variables was distributed to one thousand mainlanders in Taiwan, at a significant period, $1997^{18}$. This questionnaire enabled us to measure statistically a complex, emotional and sensitive question, one hitherto confined until recently to the fields of political prejudice and psychological resentment. To highlight this identification with Taiwan, we employed, among others, the variable of the respondents' position on the question of unification between the two sides of the Strait. This question, as we have said, is crucial. Therefore, we framed the unification question in two very different ways, to try and determine whether there was any difference between a position of principle, theoretical, symbolic and explicit, and a non-political position, one that was felt rather than spoken, one that was hardly measurable other than through the comparison of variables: not being verbalised, this position could not, by definition, appear as an answer to a clear and direct question. First, the question was asked directly: "Do you think that the government of the Republic of China cannot in any circumstance compromise on the necessity of supporting the policy of unification between the two sides of the Taiwan Strait?" The second question was put indirectly, respondents having to rate in order of importance six policies-six possible priorities for the government-one of which was unification between the two sides. The first 
question led us to a surprise: scarcely more than half the respondents (50.3\%) declared they believed so. The way that the question had been framed, though it did push them towards a clear statement of principle, did not "commit" them beyond the principle: one might have expected a far higher yes, in the area of $80 \%$. Less surprising, and helping to explain this $50.3 \%$ average, was the generational phenomenon, which showed great differences in the likelihood of a yes vote according to people's age groups. The generation born on the mainland recorded 78.3\%; the generation born in Taiwan between 1945 and 1968, 41.7\%; and the generation born in Taiwan between 1969 and 1981, only $34.7 \%$. The younger the age-group, the greater the number of mainlanders who challenge what is, for the supporters of unification, an absolute imperative.

We found a surprising confirmation of this phenomenon when the answers to the second question were examined. The number of respondents who chose cross-Strait unification as the government's first desirable priority, ahead of the five other available proposals (reforming the administration, improving economic conditions, battling against dirty money, raising Taiwan's profile on the international stage and protecting the environment) was only $5.4 \%$, a particularly low figure, and one to challenge many prejudices. $1.2 \%$ put unification second; $1.7 \%$ put it in third place; and only $5.8 \%$ put it even fourth. The largest groups of respondents were those who put unification down as their last but one priority or as the last of all the six choices offered: $30 \%$ and $55.6 \%$ respectively. That brings to $85.6 \%$ of those mainlanders approached the number of those considering unification as coming last when compared with other, more domestic, political priorities. While that does not mean that unification is not a priority for them-it was proposed, like the others, as a possible priority and was chosen, whatever the rank, by a huge majority-it does appear to be the first priority for only a tiny minority. Here we had a tangible measurement of their being rooted in Taiwan, a measurement confirmed by many other variables in our questionnaire ${ }^{19}$. So there is now, in the configuration of the mainlanders' national identification, an evident Taiwanese centre, whose growing importance challenges the very principle, up to now unassailable, of unification. This is an important element in the crisis mentality that drives the Blues; the unification objective among the mainlanders themselves is unstable and fragile; and, as the re-unifying ideology runs out of steam, its very survival comes under threat.

Yet, the Chinese pole of national identification does not disappear as far as the Waishengren Blue voters are concerned, which puts them in a defensive posture when faced with the deepening Taiwanisation of political structures. And it would be difficult for this Chinese pole of identification to disappear: the political socialisation of the past (being educated under the Nationalists to love China) was intense; the ethnic group identification persists (the first and second generations of Waishengren tend to keep a network of relationships with mainlanders, an influence that fades away among younger people); and, although important political changes have come about in recent years, the structure of the government is still the Republic of China, which naturally helps this identification to linger on. So the national identification of the mainlanders has a twofold connection; and, while the importance of the Chinese focus cannot prevent people putting down Taiwanese roots, such roots are not yet deep enough, particularly among those born in China or socialised under the dictatorship, to challenge their ethnic, cultural and, to some extent for a few, quasi-political identification with China. The reason why mainlanders feel anxious faced with the 
successive victories of the pro-independence camp is because their identification with China leads many of them into judgements, founded or unfounded, as to the possibility and the consequences of independence.

To complete our analysis, we should also evaluate the way in which those of Taiwanese origin identify with the national object. No-one could claim indeed that only mainlanders voted for Lien Chan and Soong Chu-yu, or were drawn into the protest movement that followed the election ${ }^{20}$. How are we to explain why middle-class Taiwanese electors, in the south, speaking Taiwanese at home, considering China to be another country, vote for Lien Chan and Soong Chu-yu? Discussions with these electors reveal clearly that at the centre of their concern may be their cares about the economic situation. The value they set upon the identity debate seems minimal. Their Taiwanese consciousness, though undeniable, does not persuade them of the need to give a state to the Taiwanese nation, or a nation to the Taiwanese state-which, for some others, is a logical consequence. They reposition the debate around their personal economic situation and incline towards a "neither this nor that" view of Taiwan's future: they are afraid of independence but, even so, they do not want unification either-or we could say: they are afraid of independence, but they disagree with unification. Some of them have invested in China, and see in the building of a Taiwanese nation, because it leads to tensions with China, a loss of time, money and energy, a dangerous strategy, and all the more useless a policy since Taiwan is, in fact, already independent. For all that, it would for them be out of the question to yield unconditionally to China.

This view of things naturally arouses impatience among the theoreticians of the Taiwanese nation who, as at many earlier moments in history elsewhere in the world, are in the vanguard of public opinion. They consider that Taiwanese voters supporting the Blues are deficient in "national consciousness"-a judgement they share with many nationalists across the world; they think these people are city-dwellers with a petitbourgeois mentality and, lastly, that they are influenced by an over-simplifying discourse and led astray over the links between identity, economic development and cross-Strait relations. And it is true that during the last election campaign, the Blues played systematically on the theme of safety (jiu Taiwan), stressing the "mortal peril" in which Chen Shui-bian was reputed to place the island.

While all nationalists across the world find themselves struggling to close the gap in consciousness between them and the peoples of the nations they seek to build, it is precisely because they are nation-builders. The project they advocate is necessarily at odds with the perceptions of the masses. And the masses, understandably, are primarily concerned with their material situation; Taiwan is no exception to the rule. There is a phenomenon of predictable inertia that confronts the pro-independence camp.

What is more, the opposition unifiers play on the strong feeling among Taiwanese people (always providing there is peace) that the main thing is the economy, the material situation. The Taiwanese economy suffered the full impact of the world slowdown, which coincided with Chen Shui-bian's first term in office. Being accustomed to growth, the Taiwanese were traumatised by the economic slowdown. The feeling became widespread that the DPP, lacking much experience of power, was incompetent. Many Taiwanese go further in associating the DPP with the economic setbacks, because it seeks independence; and they associate the KMT with stability because Peking is said to prefer it, even though in other respects they reject the idea of 
Peking's control over the island. Just so long as the KMT does not propose immediate unification and at any price, many electors who want neither independence nor unification would prefer a Taiwanised KMT to a DPP that seeks to go further. The KMT has played heavily on that preference; and the inner meaning of the pan-Blue camp's Taiwanese refrain "Work hard to save Taiwan" (pa-bien kiu Taiwan) is a message designed to refocus the debate on Chen Shui-bian's economic record.

From defeat to denial of the evidence: the feeling of urgency among the supporters of unification

The Taiwanisation of the mainlanders is certainly likely to challenge how they see unification, and this induces an element of anxiety among its supporters. However, the continuing importance of the Chinese pole in the mainlanders' national identification scheme is, among them too, a source of renewed anxiety when faced with the DPP's accession to power, and then, on its re-election, with the normalisation of its power. Thus, it seems that Taiwanisation and its converse both contribute towards dramatising the issues.

The Taiwanisation movement has divided Taiwan's Chinese nationalists throughout the decade, ending by causing the defeat of the KMT in 2000. That was a major source of anxiety for the advocates of unification, as was shown by demonstrations demanding, and bringing about, the dismissal of Lee Teng-hui from the presidency of the KMT after Chen Shui-bian's victory in 2000. But they could still tell themselves that Chen had come to power because Soong Chu-yu and Lien Chan had split the opposition vote; and, once these two came together on the same presidential ticket in late spring 2003, the re-conquest of power was possible. But Chen by himself, up against these former opponents now united, could still stand up to them. When the Chinese factor made itself felt in the campaign, with the missiles, and when Chen Shui-bian proposed a referendum on the issue of sovereignty, the long-avoided question of identity exploded into the forefront of the 2004 campaign. Politicians supporting unification hounded Chen, whipping up an unusually violent campaign: exaggerating the economic difficulties, inventing stories about social instability and crime, weaving conspiracy theories about the March 19th attack, likening Chen to sinister twentieth century dictators, making personal attacks on his honesty, his intellectual capacity and his personality, and intimidating voters by brandishing the Chinese threat while citing contradictions in the independence case (they say they want peace-but building a Taiwanese nation is a provocation to China), while avoiding any thorough examination of the problem as a whole (is China's attitude legitimate? How much pure rhetoric is there in the Chinese threats? Should they really side with China simply because the electoral logic pushes them to create a distance between themselves and the party in power?), while ignoring their own contradictions (for example, countering the proposed defence referendum by declaring that China had "only" 496 missiles trained on Taiwan).

A full-scale alarmist rhetoric has finally been deployed. To the slogan of the Lien-Soong ticket ("Work hard to save Taiwan") was added in big letters over the KMT (Central Standing Committee's Headquarters) in Taipei, the slogan "Change Starts Now" (gaibian, cong xianzai kaishi), then "Change, to Have Hope" (gaibian, jiu you xiwang). It was necessary to "Save Taiwan" from a "Dictator", from "Economic Ruin", and from the direct threat of the "Disappearance of the Country" (of the Republic of China). The Blues made numerous comparisons between Chen Shui-bian and Adolf Hitler, while one 
electoral poster pointed out that Bin Laden's choice or Saddam Hussein's preference was for Chen. The candidate for Vice-President, Soong Chu-yu, declared himself a few days after the televised debate between the two candidates for the presidency: "Mr Chen Shui-bian says that he has never changed his hair-style. Hitler never changed his moustache, either." The description of Chen Shui-bian as a dictator was directly repeated in numerous speeches and electoral rallies, right up until the warning issued by a lecturer at Taiwan University, Chu Yun-peng, also a mainlander, on the eve of polling day: "Chen Shui-bian has already brought a legal action against the press. Have we ever heard of a democratic leader taking the press to court? If Chen Shui-bian is reelected, he will bring back dictatorship and muzzle the media" ${ }^{21}$. These accusations are, in fact, simply in the line of those made by the unifying New Party during the 1990s against Lee Teng-hui, accusing him of being a dictator even as the democratic reforms were going ahead, and with them the identity transition that destroyed any illusions that unification might be a prospect for the near future.

The extreme nature of these remarks is such that one can see in them as much the product of sharp anxiety as of any calculated manipulation of information. In a letter addressed a week after the elections to Washington's representative in Taipei, Barbara J Schrage, some of Lien's supporters ended an emotional tirade against Chen Shui-bian with the words: "We w[ill] always remember him as the murderer of Taiwan's democracy on March 19" (the date of the assassination attempt). In the letter, they draw attention to lies by the Secretary General of the Presidency, Chiou I-jen who, they said, dragged up the theory of a "conspiracy between the opposition party and mainland China". We followed his statement live, but we have no memory of any such comment. One can see in this, doubtless, an interesting phenomenon with each side accusing the other of being manipulators.

We should mention, to finish, the televised intervention of Sisy Chen, an independent politician who has for a long time been in the DPP camp and has become very critical of Chen Shui-bian. On the evening of the attack on him, she appeared on television, declaring "It's all fake; this is a plot; I have the proof". However, she was never able to provide it. A month later, confronted with the row over the affair, she admitted, "I am not responsible for my words," adding, "I based myself on information that the KMT had passed to me, with the full knowledge of Lien Chan." Her intervention on the evening of the assassination attempt had likely been decided upon as an emergency response to the first opinion polls after the attack, which indicated an emotional reaction by voters in favour of Chen Shui-bian.

As for the theme of the destruction of Taiwan's political system, this was used right up to the very last day by the Blue camp: while on the day of the elections any political advertisements in the media were forbidden by law, the Lien-Soong camp published a half-page advert on the front pages of the island's main newspapers: against the background of the colours of the Republic's flag was printed the slogan, "We can never let this flag disappear from the surface of the earth!", exploiting fears that they had stirred up in the electorate over the preceding months.

A feeling of panic

The anxiety felt by conservative mainlanders, their difficulty in accepting the changes in progress, and the repeated manipulation by politicians supporting unification and seeking to hang onto their electoral support have led to record-high emotional investment. As in 2000, mainlanders who would ordinarily pass unnoticed have been 
claiming themselves convinced that newly elected Taiwanese would one day come to "assassinate" them. This kind of talk is completely out of step with reality, in a civil society that remained calm even during the protest demonstrations. It reflects a morbid fantasy, which outrageously anticipates a revenge campaign by the islanders. Indeed, the mainlanders have a guilty conscience, and are trying to conceal it: for fifty years they lent their support to a dictatorial regime maintained with an iron hand by a minority from outside, one that had colonised Taiwan and crushed its cultures. They, the small minority of mainlanders, who had arrived in rags, with a charismatic but defeated leader... Their outburst this year has its origins in a deep emotional indebtedness going back to the traumatic conditions of their arrival in the 1949 debacle. This emotional investment, with its doom-laden tendency, explains why the tears shed on losing the election were an indication less of a disappointment over the result than of a deep anxiety about the future.

The local Blue leaders, whom we interviewed the day before the election and on polling day, in Taipei, Tainan and Kaohsiung, recognised the risks of rioting within their camp in the event of defeat, and for a good reason: they had themselves intensely mobilised the troops for a decisive election. In the advert they published on polling day, you can also read these very significant words, that we would certainly not hear in Western democracies: "Great people, today you must make a decisive choice". Yet, despite a dangerous emotional saturation, the Blue camp's chiefs have poured oil on the fire at the most crucial moment, immediately after their condemnation of the voting results. They did this knowingly, taking turns one after another, day and night, for weeks on end, lavishing food and drink on the demonstrators along Kaitagelan Avenue in Taipei, to keep them there for as long as possible and in the largest numbers. They acted deliberately in a situation that was known to be explosive. Panic then took over among a considerable number of mainlanders, who lost in the frenzy of defeat the most elementary capacity to see what was coming; this in turn led them to believe in the least credible of conspiracy theories such as those circulating about the March 19th attack $^{22}$.

48 More than a month after the election, the unifiers were still consumed by a complete "belief system" in which every event, every declaration, every political action was systematically interpreted within the model of a generalised conspiracy by the Greens aimed at "making China disappear" (qu Zhongguohua) from Taiwanese culture, and at "driving the mainlanders into the sea". For weeks after the election, some mainlanders saw civil war all around them, whereas Taiwan is at peace. Locked into a siege mentality, they felt themselves threatened with physical and political annihilation whereas, apart from a few fundamentalists among the pro-independence militants, no one is thinking of throwing them out.

Worryingly, this emotional tide has affected this time the young mainlanders, those among whom Taiwanisation has been shown to be natural. This is a new phenomenon. At one moment, a very close mainlander friend insulted us as we were taking a photo of an anti-Lee Teng-hui slogan posted over the KMT Party Headquarters. At another moment, a mainlander acquaintance threw in the dustbin all her green clothes saying she could not stand them any more, while another woman reassured herself that some magazine was on her side when she saw that its cover was mainly blue. Another man was sorry that his favourite tea was green tea: in the space of a few weeks, the word had become an obsession. Many of the mainlanders think that the sinister period of the 
"white terror" during the 1950s (baise kongbu) is now being repeated in the form of a "green terror" (lüse kongbu), from which they will not physically escape. In the history of the mainlanders in Taiwan, there have been only two precedents for such an atmosphere: the transfer to Taiwan of the main contingent of mainlanders fleeing from the Communists in 1949-50, and the anxieties felt over the death of Chiang Ching-kuo in January 1988 and over his replacement by the first Taiwanese President in history, Lee Teng-hui.

50 The only positive consequence, perhaps, of this traumatic atmosphere is the high turnout recorded for the Presidential election: $80.2 \%$. Tens of thousands of Taiwanese living abroad came home to vote. On polling day, all the planes on domestic routes and all the trains leaving Taipei were overbooked, and both the north-south motorways were crammed with traffic. Old people went to vote in their wheel-chairs, sick people carrying their drips, and invalids with relatives helping them to place their votes in the ballot-boxes. A woman writing into one of the island's main dailies explained that, having been stuck for hours in a motorway traffic-jam, she had arrived at her pollingstation a few minutes after it closed, and had burst into tears of despair. Everyone knew for months in advance that each vote would count, that the vote would be close. This was the consequence of what was uniquely at stake in this election. Following the start of the protests, we could see elder mainlanders asking the way so as to join the demonstrations. One of them, an old woman, said to us, "You understand, I haven't been back to Taiwan for twenty years: I don't recognise anything." Born in China, she had lived in Taiwan for a few years only, had emigrated a generation ago, had kept her Republic of China passport, had never had much connection with the island, but had come back to vote for this "very serious decision": keeping Chen Shui-bian from being, she thought, the last President of the Republic of China.

51 It is easy to understand what an intense shock the losers have suffered. We should distinguish, however, in the Blues' reaction, between the understandable feeling of frustration brought about by so narrow a defeat, and Lien Chan's immediate politicisation of the results that signalled his defeat: "an unfair election", "an invalid result" (dangxuan wuxiao), some "abnormal phenomena having taken place during the vote" and an assassination attempt of which he suggested (having the previous day declared his compassion for the victim) that Chen Shui-bian had orchestrated it and would now refuse an enquiry because he had something to hide. Was not this the endless harping on about conspiracy theory, in a camp that sees its marginalisation ever deepening?

52 A "bifurcation in history" happened with Lien Chan's declaration, as often with political declarations that have a tremendous importance on the subsequent course of events. He could simply have declared that the voting margin was so narrow that a recount was needed. Everyone would have understood, and the losers would probably have calmed down while waiting for the revised result. Lien chose the opposite strategy, refusing to play according to the rules and fulminating against embezzlements and plots. Was the election unfair? The term is not constitutional, and has no legal meaning; it is a political interpretation. If the KMT had won, would it have denounced the election as unfair? And why condemn irregularities on the announcement of its defeat without being able to furnish any proof, whereas, during the day, all the television channels had filmed the voting without finding anything to 
complain about from when the polls opened at 08:00 to when they closed at 16:00 under the supervision of representatives from each party?

Conspiracy, plot, conjuration... The oldest of explanations?

53 Allegations about a conspiracy have become a tradition over these past years in Taiwan. Ever since a Taiwanese President came to power in 1988, and since they ceased to be the dominant force (zhuliu) in Taiwan in the early 1990s, the conservatives of the reunifying, Nationalist movement have endlessly rehashed conspiracy theories in various forms to try and counter a revolution that, in effect, was to change profoundly the nature of Taiwan's institutions, ideology and identity. Since 2000, having become the political opposition but remained the legislative majority ${ }^{23}$, they have not played the role of a constructive opposition but resorted to what is known in Constitutional law as "legislative filibustering", or obstructing the government's programme by all means: cutting budgets, stripping legal reforms of their content, refusing to authorise extraordinary sessions; this has certainly not helped the pro-independence government to introduce its reforms. Ever since Chiang Kai-shek unified the China of the warlords in 1927, the KMT had had no experience of opposition.

This provides us with a partial reply to the question of why, if their identification is already pluralistic, do most mainlanders choose the Chinese element in their identity when they come to vote, rather than the Taiwanese element. Fear, partly justified (by China's verbal threats) and partly unjustified (because of doubts as to whether the Chinese have the real capacity to carry out these threats, at least now), as well as the anti-Waishengren chauvinism of many pro-independence militants, inevitably give the Waishengren the feeling that independence is the most dangerous solution, and that they would not have any place in a Taiwanese nation-state. This feeling of fear, faced with Taiwan's political development, is to a large extent emotional: it is, for that reason, all the more easily manipulated. This disorientation before the utter change to their landmarks, this fantasy about their own disappearance, and the ethnicist discourse of some pro-independence militants who endlessly "victimise" them: all this explains their natural reflex to vote for mainlander and Blue candidates, an ethnic reflex where it occurs, which is not shared by those of Taiwanese origin. This is how the Blue camp survives, its unifying discourse being more and more in contradiction with the fact that most of its members, including its leaders, now identify with Taiwan.

But we are dealing with the logic of democratic elections, and its principle is arithmetical: winning as many votes as possible. This logic, which leads to electioneering and populism in many modern democracies, has led the Blue camp to a simple strategy faced with its delicate situation: the manipulation-conscious, systematic and immoderate in the light of Taiwan's real situation-of the anxieties of the mainland population, disoriented because it is in the process of indigenisation, and of the Taiwanese people just coming out of a historic economic recession. Here, the unification supporters have used their last card: fear. Nevertheless, there are quite a few analysts who denounce the DPP as a risk factor, while seeing in the KMT a guarantee of stability-when it is really on the brink of collapse, and now putting everything at stake to survive.

Risks

56 Playing politics at the lowest level risks effecting everyone concerned, starting with the Blue camp, in undesirable ways. Many of its militants have been destabilised by the demonstrations, by their violence, exaggerations and lies, and by the image created of 
Taiwanese democracy. Similarly, faced with the possibility of a Green victory in the legislative elections later this year, many candidates standing under the KMT banner, those of local and Taiwanese stock, may be tempted to leave the Nationalist Party to join the Greens, as has regularly occurred in the past. If an extensive movement in this direction were to develop, it would signal one more departure from the KMT of politicians in the "Taiwanese camp"; this would certainly leave the Blues more unified, but would also push them towards an ideological repositioning in a direction that their leaders do not all wish to follow, and which would further diminish their appeal.

The strategy of the Blue camp also carries a risk for the Greens. If the attitude of the Blues led the KMT into collapsing during the forthcoming legislative elections, the Greens would then lose an enemy whose ideological contradictions, internal divisions and growing electoral weakness are so many aces to keep them in power, even under fire from politicised criticism. The disappearance of such an enemy would leave them vulnerable to damage caused by their own divisions ${ }^{24}$.

An election day poster of the pan-blue camp proclaims that the flag of the Republic of China must not disappear from the face of the earth. In compliance with the law, candidates' names are not mentioned

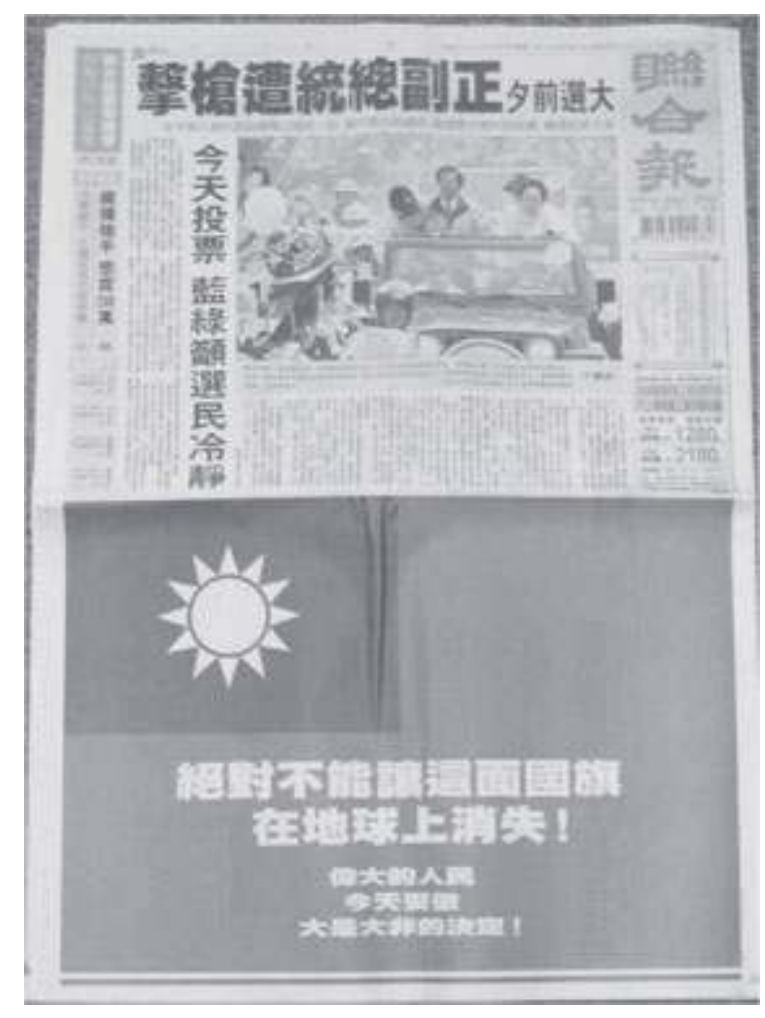

(C) Stéphane Corcuff

The fear card, lastly, puts China in a tricky position. Caught between the devil and the deep blue sea by the demonstrations, Peking finally declared that it might intervene if things turned out badly, at the moment when the demonstrations in front of the Central Election Commission were threatening to degenerate, with the first signs of physical violence in Taipei. The next day, a cadre of Soong Chu-yu's People First Party, trying to contain the violence while encouraging the mobilisation, told the excited militants: "China was only bluffing; [...] it's impossible that it would interfere in our 
affairs." A re-unifier was announcing, by the same token, that what the Blues had been brandishing for years was, to some extent, an imaginary sword.

But the most troubling question is what idea some segments of the Taiwanese society may now have of democracy. Many people now doubt whether Taiwan's democracy is really healthy, and some even wonder whether the democratic principle is justified. More seriously even, young people in Taiwan generally feel a profound disgust for politics and the spectacle that has been made of it, particularly during this campaign. Not having personal memories of dictatorship, the only reference they have is a democracy that is increasingly challenged by a radicalised question of identity. Their disgust has little in common with the disaffection that young people in other countries feel towards politics, and, should it continue that way, it may not bode well for the future of the democratic idea in Taiwan. Lastly, what one can discern behind the opposition of some of the unifiers towards Chen Shui-bian is nothing less than their fledgling? support for the democratic principle. Indeed, some of them have been slow to accept the democratic process, having been forced into it by Lee Teng-hui. This paradox of a democratic leader forcing conservatives to accept democracy and, for this, using his wide powers within the KMT is easy to understand: Lee Teng-hui was well aware that democratisation within the KMT would be dangerous for his democratic reforms across the whole society, because it would curtail his power to change things faced with the conservatives. Thus was born their accusation that Lee Teng-hui was a dictator, because he was using all the powers that the presidency of the KMT gave him to limit those of the mainlanders supporting unification, and promoting the reforms that were destabilising them. The support of these unification supporters for the current political system is permanently weakened by the combination of democratic reforms and the changing of the national identity: the one could not succeed without the other. What appears clearly since then is that, from the moment when democracy allows the people, the media or the politicians to question the legitimacy of the ideal of unification with China, the support of some Blues for the democratic principle begins to vacillate. For Taiwan's democracy, this might again be a worry for the future.

The bitter taste of democracy

The politicians of the Blue camp were for decades at the heart of a state-party, one of the most tightly-knit in the world. First, being radically opposed to independence, they found themselves watching Lee Teng-hui marginalising their power within the KMT. Then the unbelievable happened before their very eyes: the independence party came to power, putting the KMT into opposition for the first time. The policy begun by Lee Teng-hui has since been taken even further, and the candidate Chen has been reelected to sole power ahead of his two main opponents. We are bound to wonder what feelings they may have today towards a system that has allowed this process; for it is precisely by playing the democratic game that they have lost power.

61 Very early on, the leaders of the Nationalist Party opposed to Lee Teng-hui realised that he was going to change things irreversibly. In 1990, he was elected by a whisker as the KMT's official candidate for President. In 1993, the party split with the formation of the New Party, dominated by the opponents of the KMT's new leader. Then, on December 9th 1995, Lin Yang-kang and Hau Po-tsun, vice-presidents of the KMT, published an "Open Letter to the Party Comrades" in the Central Daily News (Zhongyang ribao), the party organ. They declared to everyone, "Lee Teng-hui has the ingenuity (xinji) to destroy the Party and betray the country." Lee was at that time head of the 
KMT and serving President of the Republic... But their opposition, while it was explicit and fierce, always remained within the legal limits. One can understand how this democracy might have a bitter taste for them: the democratic process was imposed on them by Lee; they played the game, even reluctantly: which ended by allowing the opposition pro-independence party to come to power, and to hang onto it. This is one of the major reasons why they hate Lee Teng-hui so fiercely, to an extent that is somewhat hard to realise outside of Taiwan, with classical democratic standards. Psychology explains this, and shows again why political science cannot avoid taking it into consideration into its analyses.

A choice between democracy and identity?

Taiwanese campaigners for independence question whether the politicians of the Blue camp identify with Taiwan. But in a political context that marginalises the unifiers, the question lies elsewhere: how can they now avoid political extinction, faced with the democratic process?

Their ambiguity towards democracy dates in fact further back than this election. It has even been there for a long time: at least since 1991, when Lee Teng-hui introduced reforms designed to lead to the re-election of the assemblies elected in 1947 in Taiwan and on the mainland. Lee chose this as the first great reform of his programme because, although it was a sensitive matter, it was the one most urgently and self-evidently needed. Yet, the conservatives desperately opposed it because it led to re-election of the assemblies on the only territory that Taipei controlled, so challenging the principle of representing the whole of China in the assemblies of the Republic. The same debate reoccurred in 1994 during the constitutional reforms leading to the election of the President of the Republic of China, no longer by the National Assembly but by the Taiwanese people voting in direct universal suffrage: this made Lee, in fact, the President of Taiwan.

Once a pro-independence President had come to power, as the Blues' anxieties were becoming real, they attempted in autumn 2000 to use the constitutional mechanism of impeachment against Chen Shui-bian, on the pretext of a political disagreement over the question of the fourth nuclear power station. Whatever may have been the terms of the debate, this was a challenge to the political responsibility of the head of state whereas, in constitutional logic, the head of state has no such responsibility in a parliamentary or presidential system, unlike the Prime Minister assuming there is one. The Blues, by manipulating a procedure that constitutional theory prescribes only as a sanction against high treason, risks giving the impression that they are not troubled by democratic principles, being ready when political questions are uppermost, to compromise with respect for the Constitution. Now this is a vital point, for it is from this respect, purely voluntary and unforced, that the Constitution draws its strength as the supreme legal text, thus stabilising a constitutional democracy. That is just one more threat to the future of democracy in Taiwan.

More recently, the Blues' attitude to a referendum shows the same ambiguities: they are particularly troubled by the idea that a referendum might one day be used to validate the island's independence and its change of name; in autumn 2003 they made every effort to block the adoption of such a law, even though it had been prescribed by the Constitution in 1947 and had been the dearest wish of the man they see as the father of their nation, Sun Yat-sen. They were embarrassed by this contradiction and finally promised to vote for the law; but they amended it as far as possible so as to strip 
it of any substance. Here again, when democracy provides a tool suitable for challenging the dogma of an "imperative unification", their support for democratic reform weakens, even disappears. It is in the light of this trait in their political psychology that one can better understand the Blues' difficulty in accepting, on March 20th 2004, the verdict of the ballot box. No proof has ever been brought in support of Lien Chan's allegations on the evening of his defeat, to the extent that a curious agreement was proposed by the Blues two weeks after the start of the demonstrations: they offered to withdraw some of their complaints in exchange for an assurance that they would not have to give proof of the irregularities they had alleged.

One can now wonder: what is the future of Taiwanese democracy when such deals are proposed by one camp and accepted by the other? What influence do Taiwanese politicians have on the Taiwanese people, with their discourse of disinformation? Once the crisis is over, but with the crisis mentality lingering on, are we to fear new, more radical developments, once the nativisation policy gets even closer to a quasideclaration of formal independence? Basically optimistic and always cheerful, the former President Lee Teng-hui told us, on the day after the election, of his "confidence in the Taiwanese people, who will not allow themselves to be fooled". Yet, we are obliged to point out that a great number of Blue militants are convinced that Chen Shui-bian, who has been awarded two international prizes for his work as a reformer and for his commitment to the defence of human rights, is a dictator. The psychological divorce between the Blues and the Greens cannot lead to a real ethnic conflict precisely because it does not follow the ethnic faultlines; but it creates a similarity between Taiwanese society today and French society at the height of the Dreyfus affair. There is no guarantee that some new element might not one day throw Taiwan into turmoil. Are not the accusations flung at Chen Shui-bian a mere psychological diversion, or do the anxieties of some key people go so far as to water down their support for the democratic principle? Are they already torn between their civic allegiance and their ethnic identification? There might be no explicit answer to this question at this moment, but the question is nevertheless legitimate. Let us just hope that it will remain a purely theoretical question.

\section{NOTES}

1. In 1986, President Chiang Ching-kuo permitted the formation, illegal at the time, of the Democratic Progressive Party (DPP, Minjindang). Fourteen years later, in 2000, the DPP came to power.

2. The Blue camp groups together the Chinese Nationalist Party (Zhongguo Guomindang or Kuomintang), the People's Party (Qinmindang) and the New Party (Xindang), the last two being formed from breakaway factions of the first at the time when it was headed by Lee Teng-hui, whose policies displeased the reunification supporters.

3. The Pan-Green Coalition consists of the Democratic Progressive Party (Minjindang) and the Taiwan Solidarity Union (Taiwan tuanjie lianmeng), founded by Lee Teng-hui after his resignation in March 2000 from the presidency of the KMT. 
4. The representative form of democracy, as tried out by the founding fathers of the American Constitution and by French and British liberals, was in part invented in order to legitimise the transition from rule by one person to rule by an elite. This elite, by concentrating power in its own hands, prevents it falling into the hands of the whole population, for fear both of the difficulty of putting direct democracy into practice and of where it might lead to. The exercise of representative democracy is entrusted to an oligarchy, democratically elected but in practice having all power at its disposal: it is the effect of passing from the principle of popular sovereignty to the practice of what is called "national" sovereignty.

5. On this subject, readers might consult our article "L'introspection han à Formose. L'affaire des manuels scolaires. Connaitre Taiwan, 1994-1997”, Etudes chinoises, vol. XX (1-2), spring-autumn 2001, pp. 41-84.

6. By the end of this new term of office, the presidency will have been held continuously by native-born Taiwanese for twenty years. Vice-President Lee Teng-hui, after stepping in as acting President after the death of President Chiang Ching-kuo in 1988 (1988-1990), was elected President of the Republic by the National Assembly (1990-1996) and then, after the Constitution was reformed in 1994, was directly elected by universal suffrage for a second term, this time of four years (1996-2000). Lee, being himself of Taiwanese origin, was President of a pro-unification Chinese Nationalist Party; however, his policy was to insist on the need for focusing political action and identification on Taiwan itself, and for putting off reunification with China until more realistic times. After leaving the Presidency of both the Republic and the Chinese Nationalist Party in 2000 he displayed far more openly his preference for independence and may be considered today as having played a central role in the building of the Taiwanese nation. As for Lee's successor, Chen Shui-bian, elected in 2000 and re-elected in 2004, he came to power with an explicitly pro-independence identity from the start. In 2002 he was elected President of the DPP. Both men regularly collaborate today in promoting the Taiwanese identity.

7. The very extensive powers wielded in Taiwan by Presidents Chiang Kai-shek (1950-1975) and Chiang Ching-kuo (1978-1988) were derived, not from the Constitution which, on the contrary, seriously curtailed them, but from their personal standing within the regime and from the notorious exceptional decrees (dongyuan panluan linshi tiaokuan), which suspended the constitutional functioning of the state. Lee Teng-hui cancelled these Temporary Dispositions in 1991 and thus deprived himself, by putting constitutional government back on the rails, of these extensive powers.

8. Very few, indeed, have denounced the KMT's suppression, over forty years, of the linguistic identity and the local culture of the island. Sometimes even they contributed directly to it in the context of their official functions: as did Soong Chu-yu, vicepresidential candidate in 2004 and fierce critic of Chen Shui-bian, during the seven years he spent as Vice-Head then as Head of the Government Information Office (1977-1984).

9. On this subject, see paragraphs 722-755 of our doctoral thesis, Une identification plurielle. Les Continentaux et la transition identitaire à Taiwan, 1988-1997, Institut d'études politiques de Paris, 2000, vol. III, pp. 618-643.

10. Sovereignty discourse in Taiwan is, indeed, a product of very specific conditions: a democratic system, one that makes its own choice of head of state, that is independent in fact but not recognised as such internationally and that is under threat from its neighbour. The island nationalism produced by Taiwanese democracy in these 
conditions is, in this case, feeble. Still too weak for the pro-independence side, necessarily too strong for the supporters of unification, it does not display the features of an exclusive ethnic nationalism, at least in its present governmental expression, aiming on the contrary to achieve a civic nationalism to include all the ethnic and cultural components of the island.

11. Between the return of Taiwan to Chiang Kai-shek's China on October 25th 1945 and the final great evacuation, early in 1955 , of an area controlled by the Nationalists, the Tachen Islands.

12. "Taiwan's 'mainlanders', a new ethnic category", China Perspectives, No. 28, MarchApril 2000, pp 71-81.

13. Young people of mainland descent left these ethnic and geographical "isolat" (a French anthropological word meaning a small group of persons with relatively few contacts with extraneous populations) where, for decades, servicemen from the mainland had been living in cramped conditions.

14. For people to switch from one camp to the other is not impossible, nor even very rare, although it is not common: we know of former adherents of unification ending by accepting the principle of independence, and former advocates of independence ending by opposing the present policy. In the first case, independence is accepted as a temporary distancing from China to preserve democracy on the island. In the second, the preservation of the Republic of China is eventually defended to prevent the proindependence activists from moving too quickly, and precipitating a crisis in the Strait that would harm both democracy itself and their own hopes for independence.

15. The phrase "identity debate" that we have used earlier is perhaps best adapted to translating this conflict between two "consciousnesses".

16. In Chinese, the phrase meaning ideology (yishi xingtai) includes the word for conscience (yishi).

17. There are, however, individuals located at the two extremities of the spectrum. Their judgements, reactions and interpretations are easy to foresee; they tend to be clearly polarised over the questions of independence and unification; and therefore such individuals are the candidates best equipped to stand for the one or the other.

18. Ten years after martial law was lifted, President Lee Teng-hui was in full possession of power and could thus introduce some bold reforms. It was also a year when psychological tension reached a high point in the decade, notably because of a hardwon constitutional reform. The government of Taiwan province had by now become superfluous, the Republic of China having been confined since 1949 mainly to that same province: it was converted into a mere commission, of only symbolic importance.

19. See our essay Feng he ri nuan. Taiwan Waishengren yu guojia rentong de zhuanbian (Light Wind, warm sun. Taiwan's mainlanders and the national identity transition), Taipei, Yunchen wenhua, 2004, 158 pp. Readers who do not read Chinese but who read French might consult volume two of our above-mentioned doctoral thesis.

20. No scientific study has yet been done on those of Taiwanese stock. Because they are not a close-knit minority, but a majority composed of various communities, how is one to choose, across the whole island, a representative sample, especially if one wishes to retain our principle of an approach to national identification based on a large number of variables? The perceptions that follow are not, therefore, based on a statistical study. They derive from practical experience in the field.

21. Presentation made to international observers and foreign journalists in the offices of the KMT research foundation in Taipei, on March 19th. 
22. Suggesting, for instance, that an imitation bullet had been fired from inside the car, and that the holed windscreen had been a mock-up, prepared in advance.

23. Firstly by themselves until 2001, then in the context of a coalition. In the present legislature, which will stand down on November 30th 2004, the Blues are one vote short of an absolute majority, and thus depend on one independent vote, which does allow room for debating but assures them of a majority in many cases.

24. For this reason, Lee Teng-hui's political forces and the party that he founded, the Taiwan Solidarity Union (TSU) seemed after the Presidential election quite hesitant about inviting these Blue politicians to join them in the Green camp; but the TSU's strategists were considering it by the time this paper was written. 